\title{
Can Aerosols and Wastewater be Considered as Potential Transmissional Sources of COVID-19 to Humans?
}

\author{
Soraia El Baz ${ }^{1 *}$, Boujamâa Imziln ${ }^{1}$
}

\begin{abstract}
${ }^{1}$ Laboratory of Microbial Biotechnologies, Agrosciences and Environment (BioMAgE), Cadi Ayyad University, Faculty of Sciences Semlalia, P.O. Box 2390, Marrakech 40000, MOROCCO

*Corresponding Author: soraiaelbaz@yahoo.ca
\end{abstract}

Citation: El Baz, S. and Imziln, B. (2020). Can Aerosols and Wastewater be Considered as Potential Transmissional Sources of COVID-19 to Humans?. European Journal of Environment and Public Health, 4(2), em0047. https://doi.org/10.29333/ejeph/8324

\begin{tabular}{|c|c|}
\hline ARTICLE INFO & ABSTRACT \\
\hline Received: 18 Apr. 2020 & $\overline{\text { In view of the current situation regarding the COVID-19 disease, recently, published studies have proved the }}$ \\
\hline Accepted: 23 May 2020 & $\begin{array}{l}\text { higher aerosol and surface stability of COVID-19. This virus, can survive long time on wastewater and aerosol. } \\
\text { Therefore, its transmission via contaminated waste surfaces and airborne transmission through aerosols can } \\
\text { occur besides close-distance contacts. This article discusses the potential presence of the COVID-19 pandemic } \\
\text { on aerosol, wastewater and sewage sludge. This article highlights the need for health protection, which should } \\
\text { be considered to curb the rapid spread of COVID-19. An eventual development of new specific techniques would } \\
\text { be of great interest for controlling the environmental dissemination of these viruses in the current and eventual } \\
\text { future outbreaks. Finally, levels of infectious virus in poor countries like Africa could be increase, due to lack of } \\
\text { wastewater treatment. So, it is clear that to limit the transmission of COVID-19, a high disinfection methods and } \\
\text { sustainable international collaborative work are required. Meanwhile, further research is important to develop } \\
\text { new strategies to limit the transmission of COVID-19 and to avoid a serious second wave of the pandemic or even } \\
\text { third waves of COVID-19 infections. }\end{array}$ \\
\hline
\end{tabular}

Keywords: coronavirus, COVID-19, wastewater, feces, aerosols, airborne transmission

\section{INTRODUCTION}

The current outbreak of novel coronavirus (COVID-19), as declared by World Health Organization (WHO) is a global pandemic. By May 13, 2020, the number of infected cases had reached 4 million in world and the number of global deaths reached 283153 (WHO, 2020b). As the number of confirmed cases continues to rise, most countries have applied social distance which had an impact on the economic development and social stability. New severe acute respiratory syndrome coronavirus 2 (SARS-CoV-2) belong to the Coronaviridae family and is a small spherical particle $(\approx 100 \mathrm{~nm}$ diameter $)$, with distinctive spikes $(\approx 10 \mathrm{~nm})$, and gave virions the appearance of a solar corona (Zhu et al., 2020). Among the enveloped viruses, coronaviruses are single-stranded positivesense RNA viruses (La Rosa et al., 2020).

Most reports have confirmed that the primary transmission mode of SARS-CoV-2 is person-to-person contact transmission, can occur by direct and indirect contact via respiratory droplets (such as breathing, sneezing, coughing) and close contact with infected people or with surfaces and fomites in the immediate environment or with objects used on the infected person (Morawska, 2006). Moreover, recent report reveal that human can transmit SARS-CoV-2 virus to some animal like pets, but until know the infected animals are not able to transmit coronavirus to human again (El Baz and Imziln, 2020).

Recently, many works has mentioned that SARS-CoV-2 could survive for up to three hours maximum as aerosols to a maximum of three days on surfaces (Balachandar et al., 2020). Other report suggest that this novel coronavirus may become a seasonal infectious virus ( $Q u$ et al., 2020). Unfortunately, less study have pay attention to others main routes of transmission such as aerosol transmission, waste water, but there are important reasons to suspect they play a role in the high transmissibility of COVID-19. This article discusses the potential presence of SARS-CoV-2 on aerosol, wastewater and sewage sludge. Especially, a second wave of COVID-19 might appear later in some countries (such as Singapore), so maybe it is due to fecal transmission via aerosols and wastewater. This article also highlights the need for health protection, which should be considered to avoid a serious second wave of the pandemic or even third waves of COVID-19 infections. 


\section{COVID-19 MAY TRANSMIT THROUGH INFECTIOUS AEROSOLIZED PARTICLES}

Aerosols are solid or liquid suspensions in the air and their particle size range is $0.001-100 \mu \mathrm{m}$ (Tellier, 2009). When an infected person coughs, sneezes, breathes vigorously, or speaks loudly, the virus will be dissolved with the aerosol and become the bio-aerosols (Wang and Du, 2020). Once formed, can rapidly spread to a larger area with the assistance of the wind, including those containing viruses (Morawska et al., 2009; Zhang et al., 2013). Airborne transmission is different from droplet transmission as it refers to the presence of microbes within droplet nuclei, which are generally considered to be particles $<5 \mu \mathrm{m}$ in diameter, and which result from the evaporation of larger droplets or exist within dust particles (WHO, 2020a). Many studies have proven that aerosols played an important role in the spread of some virus. It has been determined that aerosols were one of the major reasons for the transmission and large infection outbreak of H1N1 (Maines et al., 2009; Zhang et al., 2013), severe acute respiratory syndrome (SARS) (Yu et al., 2004) and Middle East respiratory syndrome (MERS) (Adhikari et al., 2019).

During aerosol generating procedures, droplets containing infective pathogens could be deposited on the surrounding surfaces. Human coronaviruses, such as SARS and MERS, can persist on inanimate surfaces for up to 9 days, particularly when suspended in human secretion, and undergo onward transmission (Ge et al., 2020; Otter et al., 2013). But it could be enough time to reach other organisms, to mutate and change characteristics (Núñez-Delgado, 2020). In contrast, they can be efficiently inactivated by surface disinfects within one minute (Kampf et al., 2020).

Considering the similarities between the two SARS viruses and the evidence on virus transport in general, it is highly likely that SARS-CoV-2 virus also spreads by air (NASEM, 2020). According to recent study, aerosolized SARS-CoV-2 remains viable in the air for at least 3 hours with a half-life on the order of 1 hour and for up to 2 or 3 days on plastic and stainless steel surfaces; they concluded also that aerosol transmission of SARS-CoV-2 is possible (van Doremalen et al., 2020). Viable virus can indeed be emitted from an infected individual by breathing or speaking, without coughing or sneezing. The louder one speaks, the more aerosol particles are produced. So, ten-minute conversation with an asymptomatic infected individual would yield approximately 6,000 aerosol particles that could potentially transmit COVID-19 to other people (Asadi et al., 2019, 2020).

Based published studies, it is plausible that small particles containing the virus may diffuse in indoor environments covering distances up to $10 \mathrm{~m}$ from the emission sources, thus representing a kind of aerosol transmission (Morawska et al., 2009; Setti et al., 2020). So, the inter-personal distance of $2 \mathrm{~m}$ is not enough to safeguard from contagion only if everybody wears face masks in daily life activities (Morawska and Cao, 2020). However, on-field studies carried out inside Wuhan Hospitals showed the presence of SARS-CoV-2 in air samples collected in the hospitals and also in the surroundings, leading to the conclusion that the airborne route has to be considered an important pathway for viral diffusion (Setti et al., 2020).
More details were given by Liu et al. (2020) that an elevated airborne COVID-19 concentration was recorded inside the patient mobile toilet of Fangcang Hospital. This may come from either the patient's breath or the aerosolization of the virus-laden aerosol from patient's feces or urine during use. This finding supports that virus-laden aerosol deposition play an important pathway for surface contamination. Other report noticed five cases were infected with COVID-19 (one confirmed case in Mongolia and four clinical laboratory technicians in Wuhan), of whom had no contact with the confirmed cases. One possibility to explain this infection, is that the virus is transmitted through aerosol directly to people (Wang and $\mathrm{Du}, 2020$ ).

In the context of COVID-19, WHO in their report on 27 March 2020, has reported that airborne transmission may be possible, but in specific circumstances in which generate aerosols are performed such as: open suctioning, administration of nebulized treatment, manual ventilation before intubation, turning the patient to the prone position, disconnecting the patient from the ventilator and cardiopulmonary resuscitation) (WHO, 2020a).

\section{PERSISTENCE OF CORONAVIRUS IN WASTEWATER}

Hospitals are important sources of pollutants, particularly during COVID-19 pandemic, laboratory and research activities as well as medicine excretion by patients (Wang et al., 2020). According to recent case reports, SARS-CoV-2 RNA was detected in stool samples from COVID-19 patients (Holshue et al., 2020; Zhang et al., 2020c). Besides direct contact and respiratory routes, fecal transmission might be an alternative route owing to the presence and survival of SARS-CoV-2 in patient's feces (Tian et al., 2020). Also, the potential fecal-oral transmission was recently highlighted (Yeo et al., 2020), and may contaminate hands, food, and water, and may cause infection by invading the mouth and respiratory mucosa (Zhang et al., 2020c). Therefore, the involvement of fecallycontaminated food in coronavirus transmission can be considered (Mullis et al., 2012). So, an exposure to an environment contaminated with feces (such as a public toilet or poorly sanitized areas) can cause "fecal-mucosal transmission" when people touch their mouths, noses, or eyes with contaminated hands (Tian et al., 2020). In addition, some results have found that 14 patients with a positive stool test did not experience gastrointestinal symptoms and had nothing to do with the severity of the lung infection during their hospitalizations in Jinhua Municipal Central hospital in China (Zhang et al., 2020b). In fact, affected people (symptomatic and asymptomatic) could spread the viruses through their excreta (Núñez-Delgado 2020). In addition, sharing the same toilet can infect healthy family members through the fecesaerosol-respiratory (Tian et al., 2020). Importantly, prevention of fecal-oral transmission should be taken into consideration to control the spread of the virus, because potential fecal-oral transmission can last even after viral clearance in the respiratory tract (Xiao et al., 2020).

Previous studies have shown that human coronaviruses such as SARS exist and can maintain their viability and their 


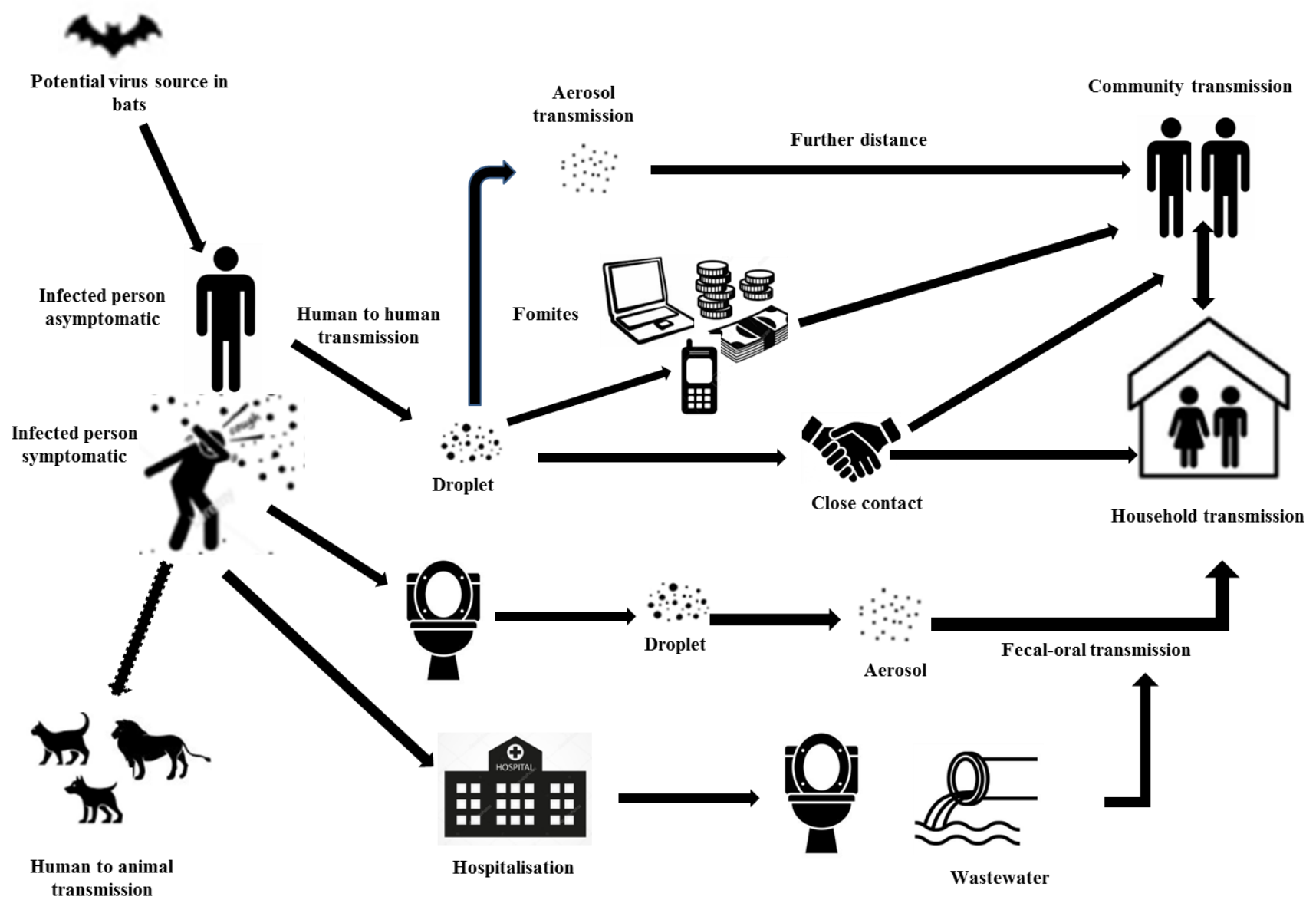

Figure 1. Different routes of transmission of COVID-19

persistence in sewage and hospital wastewater (originating from the fecal discharge of infected patients) (Casanova et al., 2009; Hung, 2003; Leung et al., 2003). Nowadays, many researchers have detected traces of COVID-19 genetic material in wastewater and sewage in the Netherlands (Lodder and de Roda Husman, 2020; Medema et al., 2020), the United States (Mallapaty, 2020; Nemudryi et al., 2020) and Sweden (Mallapaty 2020). Otherwise, it is also claimed that the virus released in wastewater system, may generate aerosols and therefore has the potential to enable airborne transmission of COVID-19 (Gormley et al., 2020). In fact, sewage from hospitals, especially infectious disease units, may contain the epidemic virus (Carducci et al., 2020). Therefore, the possibility of fecal-oral transmission of SARS-CoV-2 has implications, especially in areas with poor sanitation where diagnostic capacity might be limited, such as Africa (Lodder and de Roda Husman, 2020). It should be taken into account the consequences of wastewater and sewage sludge treatment and to evaluate the eventual subsequent spreading of COVID19 to environmental compartments (Núñez-Delgado, 2020).

In February 2020, the U.S.A Occupational Safety and Health Administration (OSHA) released that current disinfection employed in wastewater treatment plants, using oxidation with hypochlorous acid (free chlorine) or peracetic acid, and inactivation by ultraviolet irradiation, are expected to be effective in protecting people from COVID-19 (Naddeo and Liu, 2020; OSHA, 2020). Few later, for effective centralized disinfection, World Health Organization (WHO) has suggested free chlorine $\geqslant 0.5 \mathrm{mg} / \mathrm{L}$ after at least 30 minutes of contact time at $\mathrm{pH}<8.0$ (WHO, 2020c). La Rosa et al. (2020) reported that SARS-CoV-2 is very sensitive to oxidants (such as chlorine), and appears to be inactivated in water and. Unfortunately, Zhang et al. (2020a) reported an unexpected presence of SARS-CoV-2 viral RNA in septic tanks of Wuchang Fangcang Hospital after disinfection with $800 \mathrm{~g} / \mathrm{m} 3$ of sodium hypochlorite. SARS-CoV-2 might be embedded in patient's feces, protected by organic matters from disinfection, and slowly release when free chlorine declines, and potentially contributing to its spread through drainage pipelines. So, Current recommended disinfection strategy by WHO might not secure a complete removal of SARS-CoV-2 in medical wastewater. The importance of using best management practices for waste handling and hygiene should be reemphasized at this time when self-quarantine at home are common practice patients with mild symptoms for at least 14 days (Nghiem et al., 2020). The same study also indicated that a delay in waste collection time of 72 hours (which is the likely life span of COVID-19 in the environment) is recommended. So, implementation of the waste collection requires a high level of coordination between health authorities and waste services sector (Nghiem et al., 2020).

\section{RECOMMENDATIONS AND CONCLUSION}

Based on all studies cited previously, we have summarized in Figure 1 different routes of transmission of COVID-19. Therefore, important implications for the public health 
prevention and medical staff protection against airborne transmission in indoor scenarios should be taken (Liu et al., 2020; Qian and Zheng, 2018; Xiao et al., 2020): 1) the renovation of large stadiums as field hospitals with nature ventilation and protective measures is an effective approach to quarantine and to reduce the COVID-19 transmission among the public; 2 ) the use of high level protection masks especially for medical staff with direct contact with the COVID-19 patients or with long stay in high risk area; 3) avoid air recirculation, 4) avoid staying in another person's direct air flow, minimizing the number of people sharing the same environment and avoiding busy crowds; 5) the proper use and cleaning of toilets (by natural ventilation and sterilization), as a potential spread source of coronavirus with relatively high risk caused by aerosolization of virus and contamination of surfaces after use; 6 ) surface sanitization of the apparel before they are taken off may also help reduce the infection risk for medical staff, the virus may be resuspended from the contaminated protective apparel surface to the air while taking off and from the floor surface with the movement of medical staff; 7) rRT-PCR testing for COVID-19 from feces should be performed routinely in patients with COVID-19 and their hospitalization should continue if feces test results are positive by rRT-PCR testing.

Finally, levels of infectious virus in poor countries like Africa could be increase, due to lack of wastewater treatment plants. It is clear that the control and prevention of COVID-19 require a high disinfection methods and sustainable international collaborative work and data sharing. Meanwhile, further research is important to develop new strategies to limit the transmission of COVID-19 and to avoid a serious second wave of the pandemic or even third waves of COVID-19 infections.

\section{ACKNOWLEDGEMENTS}

The authors want to acknowledge the Editorial office of the journal and all the anonymous reviewers.

\section{REFERENCES}

Adhikari, U., Chabrelie, A., Weir, M., Boehnke, K., McKenzie, E., Ikner, L., ... Mitchell, J. (2019). A Case Study Evaluating the Risk of Infection from Middle Eastern Respiratory Syndrome Coronavirus (MERS-CoV) in a Hospital Setting Through Bioaerosols. Risk Anal, 39(12), 2608-2624. https://doi.org/10.1111/risa.13389

Asadi, S., Bouvier, N., Wexler, A. S. and Ristenpart, W.D. (2020). The coronavirus pandemic and aerosols: Does COVID-19 transmit via expiratory particles? Aerosol Sci Technol, 0, 1-4. https://doi.org/10.1080/02786826.2020. 1749229

Asadi, S., Wexler, A. S., Cappa, C. D., Barreda, S., Bouvier, N. M. and Ristenpart, W. D. (2019). Aerosol emission and superemission during human speech increase with voice loudness. Sci Rep, 9(1), 2348. https://doi.org/10.1038/ s41598-019-38808-Z
Balachandar, V., Mahalaxmi, I., Kaavya, J., Vivekanandhan, G., Ajithkumar, S., Arul, N., ... Mohana Dev, S. (2020). COVID19: emerging protective measures. Eur Rev Med Pharmacol Sci, 24(6), 3422-3425. https://doi.org/10.26355/ eurrev_202003_20713

Carducci, A., Federigi, I., Liu, D., Thompson, J. R. and Verani, M. (2020). Making waves: Coronavirus detection, presence and persistence in the water environment: State of the art and knowledge needs for public health. Water Res, 179, 115907. https://doi.org/10.1016/j.watres.2020.115907

Casanova, L., Rutala, W. A., Weber, D. J. and Sobsey, M. D. (2009). Survival of surrogate coronaviruses in water. Water Res, 43(7), 1893-1898. https://doi.org/10.1016/j.watres. 2009.02.002

El Baz, S. and Imziln, B. (2020). Can Human Transmit COVID19 to Animal?. J Clin Exp Invest, 11(3), em00746. https://doi.org/10.5799/jcei/8262

Ge, Z.-y., Yang, L.-m., Xia, J.-j., Fu, X.-h. and Zhang, Y.-z. (2020). Possible aerosol transmission of COVID-19 and special precautions in dentistry. J Zhejiang Univ Sci B, 1-8. https://doi.org/10.1631/jzus.B2010010

Gormley, M., Aspray, T. J. and Kelly, D. A. (2020). COVID-19: mitigating transmission via wastewater plumbing systems. The Lancet Global Health, 8(5), e643. https://doi.org/10.1016/S2214-109X(20)30112-1

Holshue, M. L., DeBolt, C., Lindquist, S., Lofy, K. H., Wiesman, J., Bruce, H., ... and Pillai, S. K. (2020). First Case of 2019 Novel Coronavirus in the United States. $N$ Engl J Med, 382(10), 929-936. https://doi.org/10.1056/NEJMoa2001191

Hung, L. S. (2003). The SARS epidemic in Hong Kong: what lessons have we learned? J $R$ Soc Med, 96(8), 374-378. https://doi.org/10.1258/jrsm.96.8.374

Kampf, G., Todt, D., Pfaender, S. and Steinmann, E. (2020). Persistence of coronaviruses on inanimate surfaces and their inactivation with biocidal agents. I Hosp Infect, 104(3), 246-251. https://doi.org/10.1016/j.jhin.2020.01.022

La Rosa, G., Bonadonna, L., Lucentini, L., Kenmoe, S. and Suffredini, E. (2020). Coronavirus in water environments: Occurrence, persistence and concentration methods - A scoping review. Water Res, 179, 115899. https://doi.org/10.1016/j.watres.2020.115899

Leung, W. K., To, K. F., Chan, P. K., Chan, H. L., Wu, A. K., Lee, N., Yuen, K. Y. and Sung, J. J. (2003). Enteric involvement of severe acute respiratory syndrome-associated coronavirus infection. Gastroenterology, 125(4), 1011-1017. https://doi.org/10.1016/s0016-5085(03)01215-0

Liu, Y., Ning, Z., Chen, Y., Guo, M., Liu, Y., Gali, N. K., ... Lan, K. (2020). Aerodynamic Characteristics and RNA Concentration of SARS-CoV-2 Aerosol in Wuhan Hospitals during COVID-19 Outbreak. bioRxiv, 2020.2003.2008. 982637. https://doi.org/10.1101/2020.03.08.982637

Lodder, W. and de Roda Husman, A. M. (2020). SARS-CoV-2 in wastewater: potential health risk, but also data source. The lancet Gastroenterology \& hepatology. https://doi.org/10.1016/S2468-1253(20)30087-X 
Maines, T. R., Jayaraman, A., Belser, J. A., Wadford, D. A., Pappas, C., Zeng, H., ... Tumpey, T. M. (2009). Transmission and pathogenesis of swine-origin $2009 \mathrm{~A}(\mathrm{H} 1 \mathrm{~N} 1)$ influenza viruses in ferrets and mice. Science (New York, NY), 325(593), 484-487. https://doi.org/10.1126/science

Mallapaty, S. (2020). How sewage could reveal true scale of coronavirus outbreak. Nature, 580(7802), 176-177. https://doi.org/10.1038/d41586-020-00973-x

Medema, G., Heijnen, L., Elsinga, G., Italiaander, R. and Brouwer, A. (2020). Presence of SARS-Coronavirus-2 in sewage. medRxiv, 2020.2003.2029.20045880. https://doi.org/10.1101/2020.03.29.20045880

Morawska, L. (2006). Droplet fate in indoor environments, or canwe prevent the spread of infection? Indoor air, 16(5), 335347. https://doi.org/10.1111/j.1600-0668.2006.00432.x

Morawska, L. and Cao, J. (2020). Airborne transmission of SARS-CoV-2: The world should face the reality. Environ Int, 139, 105730. https://doi.org/10.1016/j.envint.2020.105730

Morawska, L., Johnson, G. R., Ristovski, Z. D., Hargreaves, M., Mengersen, K., Corbett, S., ... Katoshevski, D. (2009). Size distribution and sites of origin of droplets expelled from the human respiratory tract during expiratory activities. $J$. Aerosol Sci, 40(3), 256-269. https://doi.org/10.1016/ j.jaerosci.2008.11.002

Mullis, L., Saif, L. J., Zhang, Y., Zhang, X. and Azevedo, M. S. (2012). Stability of bovine coronavirus on lettuce surfaces under household refrigeration conditions. Food microbiol, 30(1), 180-186. https://doi.org/10.1016/j.fm.2011.12.009

Naddeo, V. and Liu, H. (2020). Editorial Perspectives: 2019 novel coronavirus (SARS-CoV-2): what is its fate in urban water cycle and how can the water research community respond? Environ Sci: Water Rese Tech, 6(5), 1213-1216. https://doi.org/10.1039/D0EW90015J

NASEM (2020). National Academies of Sciences, Engineering and Medicine: Rapid Expert Consultation on the Possibility of Bioaerosol Spread of SARS-CoV-2 for the COVID-19 Pandemic (April 1, 2020). Washington, DC: The National Academies Press.

Nemudryi, A., Nemudraia, A., Surya, K., Wiegand, T., Buyukyoruk, M., Wilkinson, R. and Wiedenheft, B. (2020). Temporal detection and phylogenetic assessment of SARSCoV-2 in municipal wastewater. medRxiv, 2020.2004.2015.20066746. https://doi.org/10.1101/2020. 04.15.20066746

Nghiem, L. D., Morgan, B., Donner, E. and Short, M. D. (2020). The COVID-19 pandemic: considerations for the waste and wastewater services sector. Case Studies in Chemical and Environmental Engineering, 100006. https://doi.org/ 10.1016/j.cscee.2020.100006

Núñez-Delgado, A. (2020). What do we know about the SARSCoV-2 coronavirus in the environment? Sci Total Environ, 727, 138647-138647. https://doi.org/10.1016/j.scitotenv. 2020.138647

OSHA (2020). Standards and directives for COVID-19, United States of America Occupational Safety and Health Administration. https://www.osha.gov/SLTC/covid-19/ standards.html
Otter, J. A., Yezli, S., Salkeld, J. A. and French, G. L. (2013). Evidence that contaminated surfaces contribute to the transmission of hospital pathogens and an overview of strategies to address contaminated surfaces in hospital settings. Am J Infect Control, 41(5 Suppl), S6-11. https://doi.org/10.1016/j.ajic.2012.12.004

Qian, H. and Zheng, X. (2018). Ventilation control for airborne transmission of human exhaled bio-aerosols in buildings. $J$ Thorac Dis, 10(Suppl 19), S2295-S2304. https://doi.org/10.21037/jtd.2018.01.24

Qu, G., Li, X., Hu, L. and Jiang, G. (2020). An Imperative Need for Research on the Role of Environmental Factors in Transmission of Novel Coronavirus (COVID-19). Environ Sci Technol, 54(7), 3730-3732. https://doi.org/10.1021/ acs.est.0c01102

Setti, L., Passarini, F., De Gennaro, G., Barbieri, P., Perrone, M. G., Borelli, M., ... Miani, A. (2020). Airborne Transmission Route of COVID-19: Why 2 Meters/6 Feet of Inter-Personal Distance Could Not Be Enough. Int J Environ Res Public Health, 17(8), 2932. https://doi.org/10.3390/ijerph 17082932

Tellier, R. (2009). Aerosol transmission of influenza A virus: a review of new studies. J $R$ Soc Interface, 6(Suppl 6), S783790. https://doi.org/10.1098/rsif.2009.0302.focus

Tian, Y., Rong, L., Nian, W. and He, Y. (2020). Review article: gastrointestinal features in COVID-19 and the possibility of faecal transmission. Aliment Pharmacol Ther, 51(9), 843851. https://doi.org/10.1111/apt.15731

van Doremalen, N., Bushmaker, T., Morris, D. H., Holbrook, M. G., Gamble, A., Williamson, B. N., ... Munster, V. J. (2020). Aerosol and Surface Stability of SARS-CoV-2 as Compared with SARS-CoV-1. N Engl J Med, 382(16), 1564-1567. https://doi.org/10.1056/NEJMc2004973

Wang, J. and Du, G. (2020). COVID-19 may transmit through aerosol. Ir J Med Sci, 1-2. https://doi.org/10.1007/s11845020-02218-2

Wang, J., Shen, J., Ye, D., Yan, X., Zhang, Y., Yang, W., ... Pan, L. (2020). Disinfection technology of hospital wastes and wastewater: Suggestions for disinfection strategy during coronavirus Disease 2019 (COVID-19) pandemic in China. Environ Pollut, 262, 114665. https://doi.org/10.1016/ j.envpol.2020.114665

WHO (2020a). World Health Organization, Scientific Brief, Modes of transmission of virus causing COVID-19: implications for IPC precaution recommendations. Available at: https://apps.who.int/iris/bitstream/handle/ 10665/331601/WHO-2019-nCoV-Sci_Brief-Transmission_ modes-2020.1-eng.pdf (Available at: 27 March 2020).

WHO (2020b). World Health Organization: Report of the WHO Joint Mission on Coronavirus Disease 2019 (COVID-19). Available at: https://www.who.int/docs/default-source/ coronaviruse/situation-reports/20200512-covid-19-sitrep -113.pdf?sfvrsn=feac3b6d_2 (Accessed: 13 May 2020).

WHO (2020c). World Health Organization: Water, sanitation, hygiene and waste management for COVID-19: technical brief; 03 March, 2020. 
Xiao, F., Tang, M., Zheng, X., Liu, Y., Li, X. and Shan, H. (2020). Evidence for Gastrointestinal Infection of SARS-CoV-2. Gastroenterology 158(6), 1831-1833 e1833. https://doi.org/10.1053/j.gastro.2020.02.055

Yeo, C., Kaushal, S. and Yeo, D. (2020). Enteric involvement of coronaviruses: is faecal-oral transmission of SARS-CoV-2 possible? Lancet Gastroenterol Hepatol, 5(4), 335-337. https://doi.org/10.1016/S2468-1253(20)30048-0

Yu, I. T. S., Li, Y., Wong, T. W., Tam, W., Chan, A. T., Lee, J. H. W., Leung, D. Y. C. and Ho, T. (2004). Evidence of Airborne Transmission of the Severe Acute Respiratory Syndrome Virus. $\quad N$ Engl J Med, 350(17), 1731-1739. https://doi.org/10.1056/NEJMoa032867

Zhang, D., Ling, H., Huang, X., Li, J., Li, W., Yi, C., ... Qu, J. (2020a). Potential spreading risks and disinfection challenges of medical wastewater by the presence of Severe Acute Respiratory Syndrome Coronavirus 2 (SARS-CoV-2) viral RNA in septic tanks of fangcang hospital. medRxiv, 2020.2004.2028.20083832. https://doi.org/10.1101/2020. 04.28 .20083832
Zhang, H., Li, X., Ma, R., Li, X., Zhou, Y., Dong, H., ... Chai, T. (2013). Airborne spread and infection of a novel swineorigin influenza A (H1N1) virus. Virol J, 10(1), 204. https://doi.org/10.1186/1743-422X-10-204

Zhang, J. C., Wang, S. and Xue, Y. (2020b). Fecal specimen diagnosis 2019 novel coronavirus-infected pneumonia. $J$ Med Virol, $\quad$ 92(6), 680-682. https://doi.org/10.1002/jmv.25742

Zhang, Y., Chen, H., Zhu, S., Shu, C., Wang, D., Song, J., ... Xu, W. (2020c). Isolation of 2019-nCoV from a stool specimen of a laboratory-confirmed case of the coronavirus disease 2019 (COVID-19). China CDC Weekly, 2(8), 123-124. https://doi.org/10.46234/ccdcw2020.033

Zhu, N., Zhang, D., Wang, W., Li, X., Yang, B., Song, J., ... Tan, W. (2020) A Novel Coronavirus from Patients with Pneumonia in China, 2019. New England Journal of Medicine 382, 727-733. https://doi.org/10.1056/NEJMoa2001017 